\title{
Some topics on geochemistry of weathering: a review
}

\author{
MILTON L.L. FORMOSO \\ Instituto de Geociências - IG, Centro de Estudos em Petrologia e Geoquímica - CPGq \\ Universidade Federal do Rio Grande do Sul - UFRGS, Av. Bento Gonçalves 9500, Bairro Agronomia \\ Caixa Postal 15001, 91509-900 Porto Alegre, RS, Brasil
}

Manuscript received on September 29, 2005; accepted for publication on March 13, 2006;

contributed by MiLTON L.L. ForMOSO*

\begin{abstract}
Weathering is a complex process comprising physical disaggregation, chemical and biological decomposition of rocks and minerals transforming complex structure minerals in simpler ones. Hydrolysis of silicates is perhaps the most important process but associated certainly to biological weathering. It is discussed the role of waters: activities/concentrations of chemical species, $\mathrm{pH}$, Eh, importance of complexes. Weathering is not only a destructive process. It can concentrate chemical species and form mineral deposits (kaolin, bauxite, $\mathrm{Fe}, \mathrm{Mn}, \mathrm{P}, \mathrm{Nb}, \mathrm{Au}$ ). Weathering studies are important in pedology, engineering geology, hydrogeology, paleoclimatology and ecology. The use of stonemeal is based upon the study of rock weathering.
\end{abstract}

Key words: chemical weathering, hydrolysis of silicates, biological weathering, physicochemical parameters of weathering.

\section{INTRODUCTION}

Weathering is a process characterized mainly by physical disaggregation and chemical decomposition of rocks transforming structures of more complex minerals in others with simpler structures. The transformation of tectosilicates (feldspars) in 1:1 phylosilicates represents well this process. At the same time the neoformation of minerals such as kaolinites, iron oxides (goethite, hematite), aluminum oxides-hydroxides (gibbsite, boehmite) which are stable at low temperature and pressure $\left(25^{\circ} \mathrm{C}, 1 \mathrm{~atm}\right)$ replacing higher temperature and pressure minerals is also representative of supergene alteration.

The supergene alteration is dependent upon climate (rainfall and temperature), topography, nature of rock (fissural system, texture and composition), influence of biosphere and controlled by drainage conditions of the profile.

\footnotetext{
*Member Academia Brasileira de Ciências
}

E-mail: milton.formoso@ufrgs.br 
The hydrolysis of silicates is the most important process during the weathering. For example:

$$
2 \mathrm{KAISi}_{3} \mathrm{O}_{8_{\mathrm{s}, \mathrm{C}, \mathrm{K} \text {-feldspar }}}+11 \mathrm{H}_{2} \mathrm{O}_{\mathrm{l}}=4 \mathrm{H}_{4} \mathrm{SiO}_{4_{\mathrm{aq}}}+\mathrm{Al}_{2} \mathrm{Si}_{2} \mathrm{O}_{5}(\mathrm{OH})_{4 \mathrm{~s}, \mathrm{c} \text { kaolinite }}+2 \mathrm{~K}_{\mathrm{aq}}^{+}+2 \mathrm{OH}_{\mathrm{aq}}^{-}
$$

$\mathrm{s}=$ solid $; \mathrm{c}=$ crystalline $;$ aq $=$ aqueous $; \mathrm{l}=$ liquid

Hydrolysis of silicates is characterized by increasing of $\mathrm{pH}\left(\mathrm{OH}^{-}\right)$, leaching of alkaline and earth alkaline cations and the partial or total leaching of $\mathrm{H}_{4} \mathrm{SiO}_{4}$. The formation of kaolinite means a partial leaching of $\mathrm{H}_{4} \mathrm{SiO}_{4}$.

The supergene alteration of rocks produces "alterites" (Figs. 1 and 2). Alterites are constituted by neoformed supergenic minerals plus some primary minerals from preexisting rocks. (Fig. 1 (Pedro 1985 in Melfi et al. 1999)).

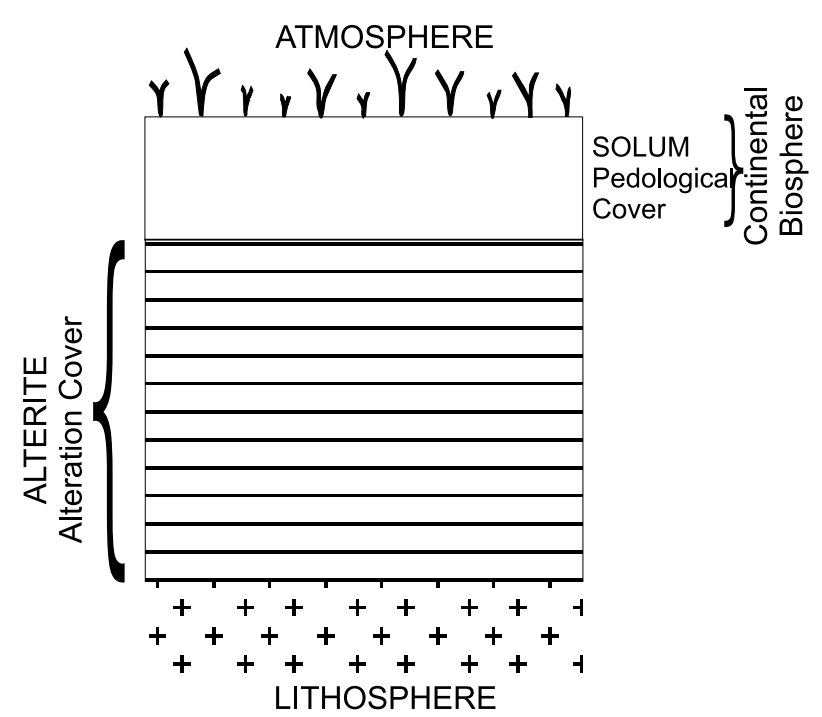

Fig. 1 - Alteration cover (alterite + soil) in relation to atmosphere and continental biosphere (Pedro 1985).

\section{CHEMICAL WEATHERING OF MINERALS}

In principle, all minerals can undergo destruction by weathering but normally the primary minerals are less resistant than the secondary ones. Minerals can be listed according to their degree of resistance to weathering. Fig. 3 displays a list of minerals in order of increasing resistance to weathering.

Note: The exact position of minerals depends upon grain size, environmental conditions. Secondary minerals are at the bottom of the list as it could be expected. (See also Loughnan 1969, Carrol 1970, Berner and Berner 1996).

The weathering of silicates especially their dissolution is not clearly explained. Muir and Nesbitt 1992, conclude that silicate dissolution occurs by means of a protective layer of altered composition which inhibits the migration of dissolved species to and from the surface of the mineral 


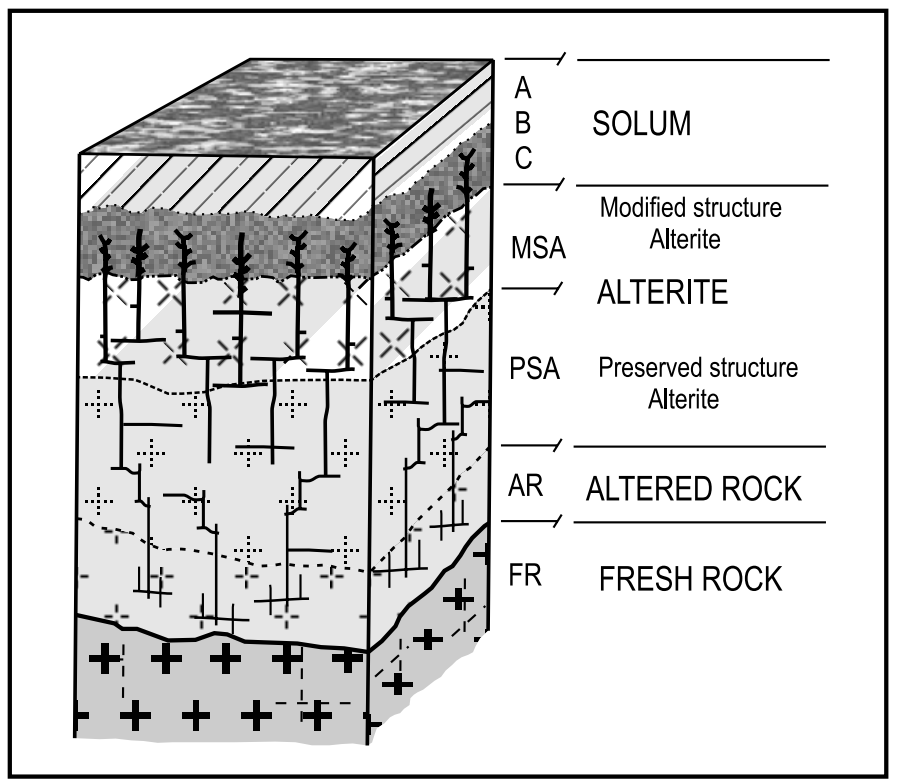

Fig. 2 - Lateritic profile of a tropical soil (Melfi et al. 1999).

\begin{tabular}{|l|}
\hline Fig. 3 - Mineral weatherability (decreasing from top to bottom) \\
\hline Pyrite \\
Calcite \\
Dolomite \\
Olivine \\
Ca - plagioclase \\
Pyroxenes \\
Ca - Na plagioclase \\
Amphiboles \\
Biotite \\
K - feldspar \\
Muscovite \\
Smectite \\
Quartz \\
Kaolinite \\
Gibbsite, hematite \\
\hline
\end{tabular}

(Berner and Berner 1996). However, detailed studies showed that the existence of the protective layer could not be proved. It seems more reasonable that most silicate react with soil solutions not as a homogeneous process but more as a selective etching controlled by crystallographical directions 
(dislocations) on the mineral surface. (Nahon 1991). In general different chemical compositions and the formation of etch pits (feldspars, pyroxenes and amphiboles) control the dissolution of minerals.

Holdsen and Berner (1979) and Meunier (2003) present a discussion on the dissolution of primary phases during the supergene alteration. Meunier (2003) emphasizes that the dissolution starts by the more energetic sites: surface, edges and vertices. The supergene alteration advances under corrosion zones formed by the coalescence of dissolution of materials at the sites of dissolution.

\section{BIOLOGICAL WEATHERING}

Although the weathering of rocks is both a mechanical and mainly a chemical process the biological influence is very important in the changes suffered by the rocks close to the surface. Acids produced around the roots of living plants and by the bacterial decomposition of plants interact with rock minerals increasing the chemical alteration of those minerals.

The upper part of the soil is a zone of intense biochemical activity. The bacterial population near the surface is large but decreases downward with a steep gradient. The organic acids mainly those with low molecular weight attack silicate minerals which commonly dissolve incongruently. For instance, an organic acid, as oxalic acid, dissociates to form $\mathrm{H}^{+}$ions:

$$
\mathrm{H}_{2} \mathrm{C}_{2} \mathrm{O}_{4 \mathrm{aq}}=2 \mathrm{H}_{\mathrm{aq}}^{+}+\mathrm{C}_{2} \mathrm{O}_{4 \mathrm{aq}}^{2-}
$$

The $\mathrm{H}^{+}$ions attack the silicate liberating its constituent chemical species:

$$
\mathrm{H}_{\mathrm{aq}}^{+}+4 \mathrm{H}_{2} \mathrm{O}_{1}+\text { silicate }=\mathrm{Al}_{\mathrm{aq}}^{3+}+\mathrm{M}_{\mathrm{aq}}^{\mathrm{n}+}+\mathrm{mH}_{4} \mathrm{SiO}_{4 \mathrm{aq}}
$$

The $\mathrm{C}_{2} \mathrm{O}_{4}^{2-}$ reacts with $\mathrm{Al}^{3+}$ to form a chelate:

$$
\mathrm{Al}_{\mathrm{aq}}^{3+}+\mathrm{C}_{2} \mathrm{O}_{4 \mathrm{aq}}^{2-}=\mathrm{Al}\left(\mathrm{C}_{2} \mathrm{O}_{4}\right)_{\mathrm{aq}}^{+}
$$

This latter reaction is a dissolution reaction very common at the uppermost acid portion of most temperate soils.

Bacterial activity is responsible by the decomposition of the $\mathrm{Al}\left(\mathrm{C}_{2} \mathrm{O}_{4}\right)^{+}$and $\mathrm{H}_{2} \mathrm{C}_{2} \mathrm{O}_{4}$. The oxalic acid and the oxalate are oxidized to $\mathrm{CO}_{2}$ and $\mathrm{HCO}_{3}^{-}$and the $\mathrm{Al}^{3+}$ is liberated and precipitates as $\mathrm{Al}(\mathrm{OH})_{3}$ or clay minerals. Thus the organic acids are responsible mainly by the low $\mathrm{pH}$ and formation of organic complexes. The process does not preserve the organic acid.

\section{WEATHERING AND SOIL FORMATION}

When alterite material comes into contact with air (atmosphere), water (hydrosphere) and biosphere (decomposing organic matter, living plants and animals) (Figs. 1 and 2), becomes organized into structural patterns (soils) under the influence of the environmental conditions. Perhaps, climate is the principal control of soil formation. High rainfall and low temperature both favor the accumulation of organic debris in soils (Loughnan 1969, Retallack 1990). Retallack (1990) displays a 
soil classification with ten types of soils according to climate and evolution. For example, oxysol is considered a deeply weathered, reddish, kaolinite, clay-rich and iron-rich soil of tropical humid climates with almost no remaining primary minerals (formerly called laterites, lateritic soils, latosols). In tropical soils there is little burial of organic matter and there is still intense leaching of cations and silica due to heavier rainfall (> $2000 \mathrm{~mm}$ per year). According to Melfi and Pedro 1977, the laterite and oxysols (latosols) cover about 65\% of Brazil's total surface, prevailing in all of Amazon, Central and Southeastern regions of this country (Fig. 4).

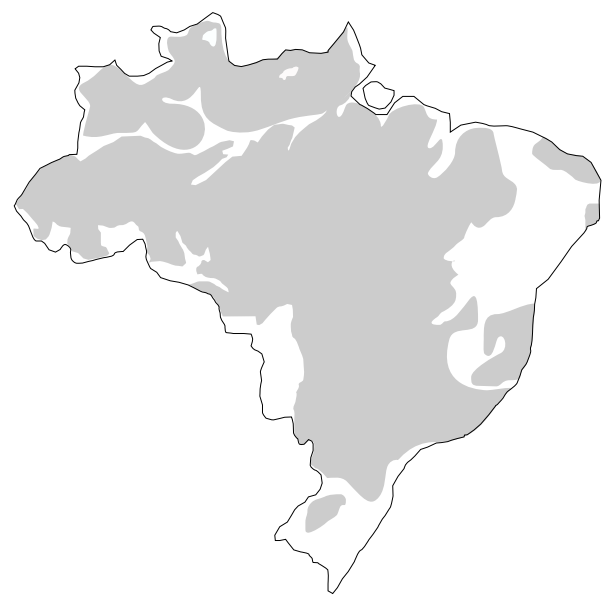

Fig. 4 - Area of lateritic cover (laterite and latosols) in Brazil (Melfi and Pedro 1977).

\section{WATERS}

Rain waters coming into contact with rocks (and derived soils) react with primary and secondary minerals or amorphous phases modifying the compositions of those waters. Rain waters increase their content of ions released from the rocks and organic matter from the biosphere constituting the soil waters. The composition of surface waters (in tropical and temperate areas) is represented by common cations $\mathrm{Ca}^{2+}, \mathrm{Na}^{+}, \mathrm{Mg}^{2+}, \mathrm{K}^{+}$and normally the principal anion is $\mathrm{HCO}_{3}^{-}$. Activity of ions, $\mathrm{pH}$, Eh, complex ions can control the composition of soil, surface and ground waters. In dilute solutions activities and concentrations are almost equal because the activity coefficients are close to one $(\mathrm{a}=\gamma \mathrm{m} ; \mathrm{a}=$ activity; $\mathrm{m}=$ concentration and $\gamma=$ activity coefficient $)$.

\section{$\mathbf{a}-\mathbf{p H}$}

$\mathrm{pH}\left(=-\log \mathrm{a}_{\mathrm{H}^{+}}\right)$is controlled by the activity of various anions and cations. The

$$
\sum \mathrm{CO}_{2}=\mathrm{aH}_{2} \mathrm{CO}_{3}+\mathrm{aHCO}_{3}^{-}+\mathrm{aCO}_{3}^{2-}
$$

(or in dilute solutions the concentrations of those anions) is very important in controlling the $\mathrm{pH}$. The presence of organic acids is also of great importance. There is a competition between the hydrolysis of silicates and the decomposition (bacterial or chemical decomposition) of organic 
material. The rain water is a dilute solution of carbonic acid and its $\mathrm{pH}$ is around 5.65 (without pollution). Rain water and surface waters coming into contact with rocks react with them which release cations, $\mathrm{H}_{4} \mathrm{SiO}_{4}$ and $\mathrm{OH}^{-}$from the hydrolysis of silicates. Normally without the presence of organic matter and vegetation, the hydrolysis of silicates predominates and the $\mathrm{pH}$ is higher than 7. The $\mathrm{OH}^{-}$predominates in comparison with organic acids and the $\mathrm{pH}$ is basic as happens in semiarid climates. In ground waters, the confined interaction between meteoric waters and rocks is still the most important factor and the influence of organic matter and products of its decomposition is much less important. The $\mathrm{pH}$ of ground waters is generally higher than 7. In surface waters (and in soil waters), the hydrolysis of silicates and the $\mathrm{OH}^{-}$produced are neutralized by the $\mathrm{CO}_{2 \mathrm{aq}}$ and by the organic acids formed in soils from the decomposition of organic debris. The resultant $\mathrm{pH}$ is lower than 7, in general, between 5.5 and 7 without anthropic pollution. In organic layers of the podsols, the $\mathrm{pH}$ may reach 3.5. The industrial contamination increases the content of sulfuric and nitric acids of the rain water constituting the acid rain. Normally the acid rain waters destroy the buffering ability of $\mathrm{HCO}_{3}^{-}$leading to the decrease of $\mathrm{pH}$ of waters.

In sea water, there is also a competition between the acid volcanic gases and the hydrolysis of silicates (Sillén 1961); the acid volcanic gases are $\mathrm{CO}_{2}, \mathrm{HCl}, \mathrm{HF}, \mathrm{SO}_{2}, \mathrm{H}_{2} \mathrm{~S}$ and the hydrolysis of silicates is from sea floor and from erosion products of continents. The resultant $\mathrm{pH}$ is around 8.2-8.4. The sea water is buffered by the system $\sum \mathrm{CO}_{2}$ especially the $\mathrm{HCO}_{3}^{-}$ion.

The $\mathrm{HCO}_{3}^{-}$presents buffering ability in sea water and also in lakes and even in some rivers. The equation $\mathrm{HCO}_{3 \mathrm{aq}}^{-}+\mathrm{H}_{\mathrm{aq}}^{+}=\mathrm{H}_{2} \mathrm{CO}_{3 \text { aq }}$ shows that the $\mathrm{H}^{+}$reacts with $\mathrm{HCO}_{3}^{-}$forming $\mathrm{H}_{2} \mathrm{CO}_{3}$ which ionizes very little. The concentration of $\mathrm{HCO}_{3}^{-}$is almost equal at $\mathrm{pH}=6.4$ and 10.3 explaining the buffering behavior of $\mathrm{HCO}_{3}^{-}$at a $\sum \mathrm{CO}_{2}=10^{-3}$ (Fig. 5). In the presence of carbonate rocks the buffering ability of $\mathrm{HCO}_{3}^{-}$increases because of higher $\mathrm{HCO}_{3}^{-}$concentration:

$$
\mathrm{H}_{\mathrm{aq}}^{+}+\mathrm{CaCO}_{3_{s}}=\mathrm{Ca}_{\mathrm{aq}}^{2+}+\mathrm{HCO}_{3_{\mathrm{aq}}}^{-} .
$$

\section{b - Eh}

The oxidation potential is another important parameter for the definition of geochemical characteristics of water. Chemical species of $\mathrm{Fe}, \mathrm{S}, \mathrm{Mn}, \mathrm{C}$ present several oxidation numbers and have their behaviors dependent of Eh. The ratio $\mathrm{Fe}^{3+} / \mathrm{Fe}^{2+}$ is very important and the tendency is the oxidation of $\mathrm{Fe}_{a q}^{2+}$ and the precipitation of $\mathrm{Fe}(\mathrm{OH})_{3}$ (or goethite and hematite). In latosols, the oxidation-reduction of the Fe species is responsible $\left(\mathrm{Fe}_{a q}^{2+}=\mathrm{Fe}^{3+}+\mathrm{e}^{-}\right)$by the dissolution - precipitation of the Fe in this type of soil associated certainly to the oscillation of water table in wet and dry seasons.

Sulfur species especially $\mathrm{S}^{2-}$ and $\mathrm{SO}_{4}^{2-}$ are important in terms of $\mathrm{Eh} / \mathrm{pH}$ and the occurrence of sulfides $\left(\mathrm{FeS}_{2}\right)$ and $\mathrm{SO}_{4}^{2-}$ are quite characteristic. In acid mine drainage (Kim and Chon 2001, Roisenberg et al. 2004), the oxidation of pyrite forms $\mathrm{Fe}_{a q}^{2+}, \mathrm{SO}_{4 a q}^{2-}+2 \mathrm{H}_{a q}^{+}$and the later oxidation of $\mathrm{Fe}^{2+}$ to $\mathrm{Fe}^{3+}\left(\mathrm{or} \mathrm{Fe}(\mathrm{OH})_{3}\right)$. The $\mathrm{pH}$ reaches values close 2 and $\mathrm{Fe}_{a q}^{3+}$ is in solution. When the $\mathrm{pH}$ increases, the $\mathrm{Fe}^{3+}$ precipitates. Manganese species present five oxidation numbers $(2+, 3+$, 


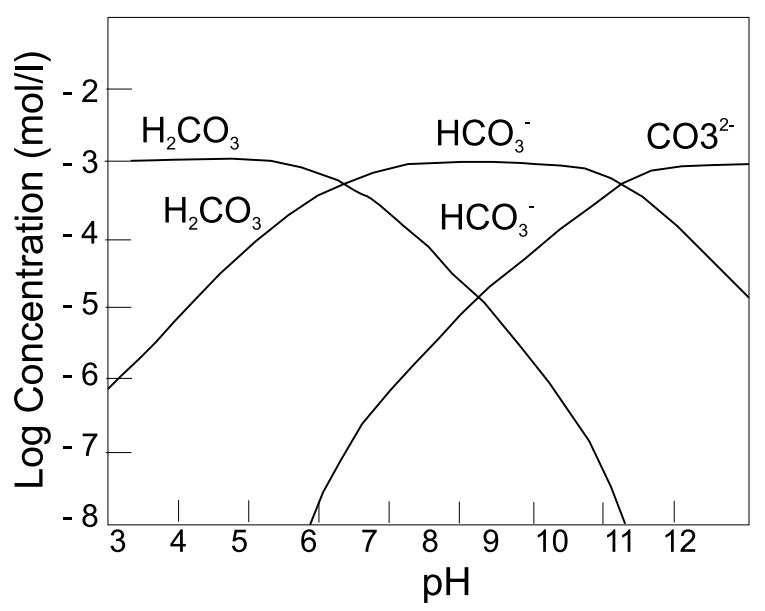

Fig. $5-\sum \mathrm{CO}_{2}$ (carbonate species) versus $\mathrm{pH}-\sum \mathrm{CO}_{2}=10^{-3} \mathrm{~mol} / \mathrm{l}$.

4+, 6+ and 7+). The $\mathrm{Mn}^{2+}, \mathrm{Mn}^{3+}$ and $\mathrm{Mn}^{4+}$ are very common and $\mathrm{Mn}^{6+}$ and $\mathrm{Mn}^{7+}$ are normally present in laboratory conditions $\left(\mathrm{MnO}_{4}^{2-}\right.$ and $\left.\mathrm{MnO}_{4}^{-}\right)$. The most common oxidation reaction in terms of manganese is $\mathrm{Mn}_{a q}^{2+}+2 \mathrm{H}_{2} \mathrm{O}_{l}=\mathrm{MnO}_{2_{s, c}}+4 \mathrm{H}_{a q}^{+}+2 \mathrm{e}^{-}$.

$\mathrm{Mn}^{2+}$ is more stable than $\mathrm{Fe}^{2+}$; in other words, the oxidation of $\mathrm{Fe} 2+$ is faster than $\mathrm{Mn}^{2+}$.

The oxidation of carbon compounds to $\mathrm{CO}_{2}$ is one of the most common oxidation processes in nature. The oxidation of carbon chemical species to $\mathrm{CO}_{2}, \mathrm{H}_{2} \mathrm{CO}_{3}$ or $\mathrm{HCO}_{3}^{-}$is very common in soils, sediments and waters.

Other oxidation of ions as

$$
\mathrm{U}_{a q}^{4+}=\mathrm{U}_{a q}^{6+}+2 \mathrm{e}^{-} ; \mathrm{Ce}_{a q}^{3+}=\mathrm{Ce}_{a q}^{4+}+\mathrm{e}^{-} \text {and } \mathrm{Eu}_{a q}^{2+}=\mathrm{Eu}^{3+}+\mathrm{e}^{-}
$$

are also important but not so common as those described above (Fe, S, Mn, C). The use of Eh-pH diagrams became very frequent in geochemical literature in the last fifty years. (Garrels and Christ 1965).

\section{c-Complex ions}

Complex ions (inorganic or organic), ionic pairs (sea water) are association between ions or with other chemical species which are responsible by the transport of chemical species in solution. The stability of complex ions depends on their constants of stability. Carbonates form more stable complexes with HREE than LREE (it depends on ionic radius).

\section{APPLICATION OF WEATHERING STUDIES}

a - The weathering is not only a destructive process. The rocks are leached by rain, soil and surface waters and many chemical species are dissolved and transported. However, the residual material may represent a concentration of chemical species constituting a mineral deposit. The final result is the formation of laterites and lateritic soils. Mineral deposits such as of $\mathrm{Fe}, \mathrm{Mn}, \mathrm{P}, \mathrm{Nb}, \mathrm{Au}$, 
kaolin and bauxites may be formed in lateritic environment. (Fig. 6). For example, the genesis of kaolin of Rio Jarí (Montes et al. 2002) is related to the weathering of Cretaceous Alter do Chão Formation (Amazon) with the neoformation of a new generation of kaolinite and leaching of iron resulting in an enrichment of kaolinite forming the important deposits of Rio Jarí kaolin. Similarly, at the high places the more advanced leaching of $\mathrm{H}_{4} \mathrm{SiO}_{4}$ led to the formation of bauxites.

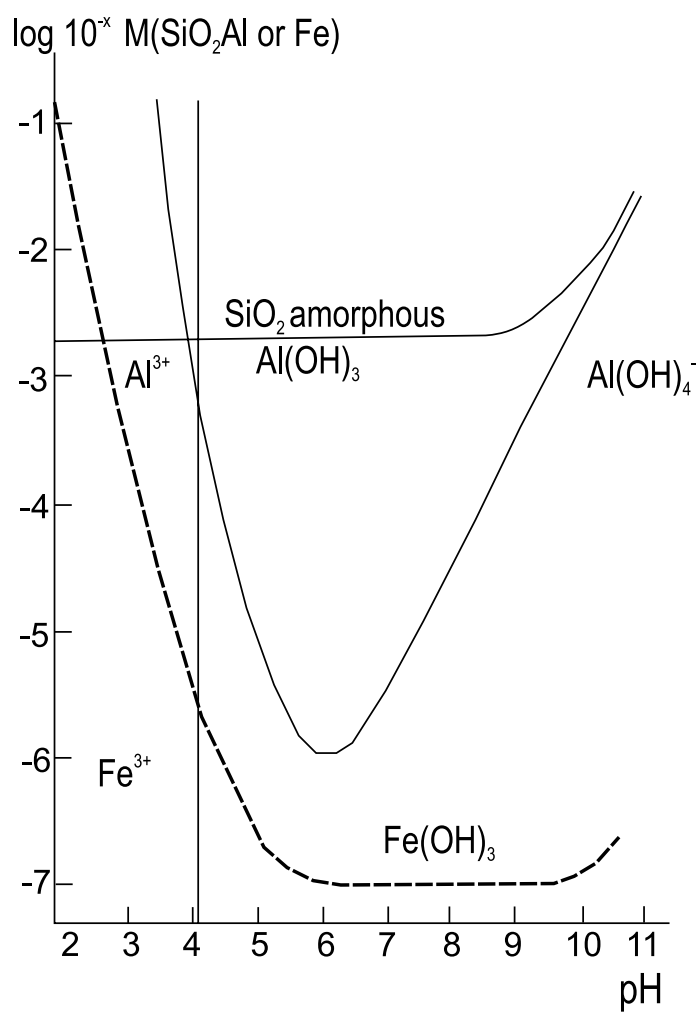

Fig. 6 - The solubility of aluminum hydroxide, amorphous silica and ferric oxide in terms of ph in superficial conditions.

In deposits of $\mathrm{Fe}$ and $\mathrm{Mn}$ is very common the oxidation and dissolution - precipitation of $\mathrm{Fe}$ and $\mathrm{Mn}$, respectively.

b - In many cases, a thick lateritic cover might hide deeper important mineral deposits and we may use geochemical prospection of soils, sediments and waters for making the prospection of the elements we look for.

c - Other important application of weathering studies is the transformation of lateritic soils (or latosols) in podzols - (Pedro 1985, Lucas et al. 1989, Melfi et al. 1999).

It is a unique example the transformation of yellow latosol in podsol that occurs in the Amazon region as an effect of hydromorphism (Melfi et al. 1999). (Figs. 7 and 8) - Latosols become white quartz sands. The soils associated to the Cretaceous Alter do Chão Formation are progressively more arenaceous toward their lower parts by the dissolution of iron species and kaolinite. The soils 
will become more acid until the forests start degrading being replaced by "campinarana", a new type of vegetation. The podzolization is characterized by the whitening of upper horizons with the individualization of a humic B horizon. The podzolided soils are formed from latosols in a transformation system (latosol - podzol).

Two types of water streams draining the system can be found. One type drains the lateritic basin; it displays clear water and is poor in dissolved organic material, high dissolved Si species and very low concentration of $\mathrm{Al}$ and $\mathrm{Fe}$ species. The second type, which drains podzolic regions, has brownish waters due to dissolved organic material and also has high concentration of iron and aluminum chemical species and low content of silicon dissolved species. The particulate fraction is important being made up of quartz, kaolinite and gibbsite. Organic-metalic complexes are responsible by the transport of $\mathrm{Al}$ and $\mathrm{Fe}$ species in solution (Melfi et al. 1999).

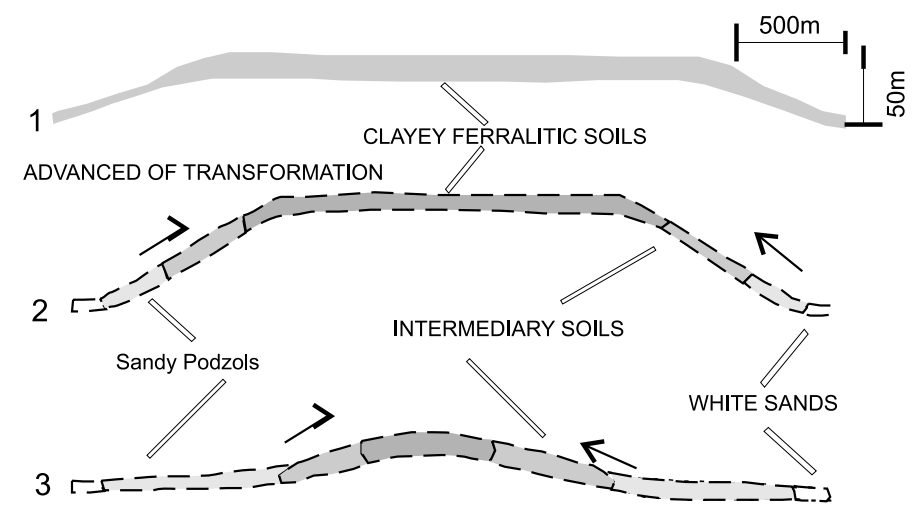

Fig. 7 - Stages of evolution of the lateritic - podzol soil systems in the Amazon Basin (Melfi et al. 1999).

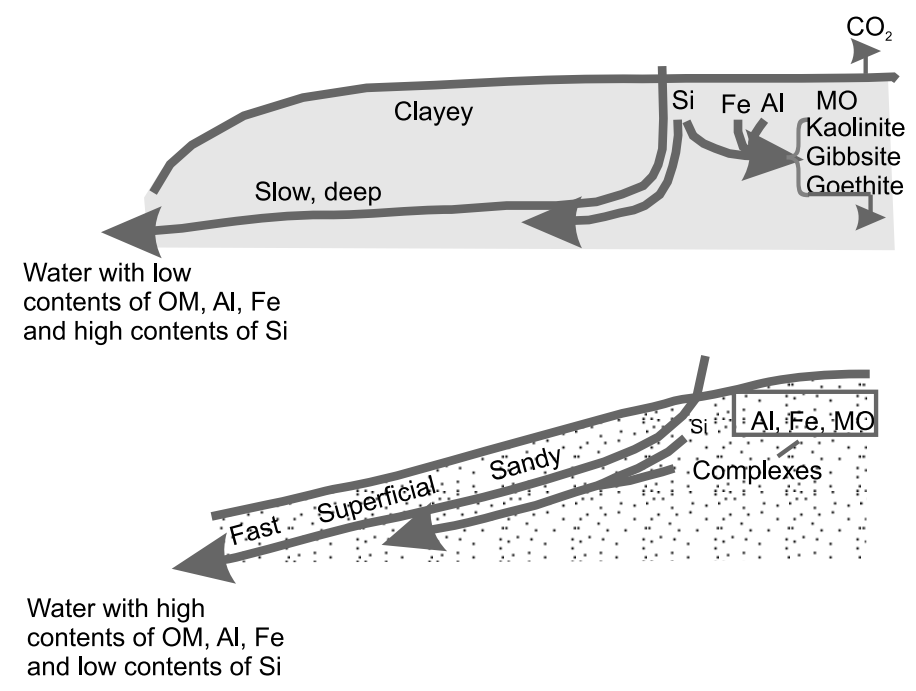

Fig. 8 - Hydrogeological of ferralic and podzolic soils. 
$\mathrm{d}$ - Studies of weathering are fundamental in Engineering Geology, Hydrogeology and practical applications of Geology. In Engineering Geology, the search of materials used in the construction of roads, dams and houses include certainly studies of supergene alteration of those materials.

In Hydrogeology, the studies of ground and surface waters obviously involve the interaction water-rock (also supergene alterations).

e - Paleoclimatology and Ecology are very dependent on research in weathering. For example, the study of alterites and soils is important because they may be associated to the development of vegetation (including forests), playing an important role in the bioclimatic balance of the planet (Melfi et al. 1999).

Alterites (especially laterites) are important marks in Paleoclimatology mainly in regions tectonically stable.

\section{STONEMEAL}

According to Leonardos and Theodoro 1999, "Under our conditions of lateritic soils we must, as an important step towards sustainable development, restore to the leached soils, the balanced inorganic meal on which crops and biodiversity can be properly fed. Stonemeal is Nature's approach to achieve overall soil fertility. The use of soluble fertilizers like NPK is only supported in limited amounts and only if coupled or preceded by stonemeal soil reminalization."

The use of stonemeal has as principle the weathering of rocks with release of major species as $\left(\mathrm{H}_{4} \mathrm{SiO}_{4}, \mathrm{Ca}^{2+}, \mathrm{Na}^{+}, \mathrm{Mg}^{2+}, \mathrm{K}^{+}\right)$or minor species $\left(\mathrm{Ni}^{2+}, \mathrm{CO}^{2+}, \mathrm{Cr}^{3+}\right.$ and others), correction of $\mathrm{pH}\left(\mathrm{OH}^{-}\right.$from hydrolysis of silicates).

The choice of the rock and conditions for stonemeal depends on various factors:

a - Chemical composition - for example, basic and alkaline rocks are ideal; rocks rich in $\mathrm{SiO}_{2}$, especially quartz, are not adequate. Volcanic rocks are very good because the supergene alteration is not slow (fine grain, sometimes glass);

b - The transport of the rocks may not be long (increase cost);

$\mathrm{c}$ - The addition of organic material together is certainly very important because it would bring about a faster alteration of the stonemeal;

$\mathrm{d}$ - Normally the stonemeal must precede (or be simultaneous with) the addition of other fertilizers.

\section{RESUMO}

Intemperismo é um processo complexo compreendendo desagregação física, decomposição química e biológica de rochas e minerais transformando minerais de estrutura complexa em estruturas mais simples. Hidrólise de silicates é talvez o mais importante mas certamente associado ao intemperismo biológico. É discutido o papel da água: atividades/concentrações de espécies químicas, pH, Eh, importância dos complexos. Intemperismo não é somente um processo destrutivo. O intemperismo pode concentrar espécies 
químicas e formar depósitos minerais (caolim, bauxita, $\mathrm{Fe}, \mathrm{Mn}, \mathrm{P}, \mathrm{Nb}, \mathrm{Au}$ ). Estudos de intemperismo são importantes em pedologia, geologia de engenharia, hidrogeologia, paleoclimatologia e ecologia. O uso de rochagem é baseado em estudo de intemperismo de rocha.

Palavras-chave: intemperismo químico, hidrólise dos silicates, intemperismo biológico, fatores físicoquímicos do intemperismo.

\section{REFERENCES}

BERNER KB AND BERnER RA. 1996. Global Enviromental: water, air and geochemical cycles. New Jersey, USA, Practice Hall, 376 p.

CARrol D. 1970. Rock weathering. New York, USA, Plenum Press.

Formoso MLL AND Cerri CC. 1999. Workshop on Tropical Soils, Academia Brasileira de Ciências, Rio de Janeiro, RJ, Brasil, 192 p.

Garrels RM AND Christ C. 1965. Solutions, minerals and equilibria. San Francisco, Freeman-Cooper, $450 \mathrm{p}$.

Holdsen GR AND BERnER RA. 1979. Mechanism of feldspar weathering. In: ExPERIMENTAL STUDIES. Geochim Cosmochim Acta 43: 1161-1171.

KIM JY AND CHON HT. 2001. Pollution of a water course impacted by acid mine drainage in the Imgok creek of the Gangreung coal field, Korea. Appl Geochem 16: 1387-1396.

LeOnARdos OH ANd TheOdoro SH. 1999. Fertilizing tropical soils for sustainable development. In: Formoso MLL AND CERri CC (Workshop on Tropical Soils), Academia Brasileira de Ciências, p. 143-153.

Loughnan F. 1969. Chemical weathering of the Silicate Minerals, New York, USA.

LUCAS Y. 1989. Systémes pédologiques en Amazonie brésilienne. Equilibres, déséquilibres et transformations. Thèse Doc, Univ Poitiers, 157 p.

Melfi AJ and Pedro G. 1977. Estudo Geoquímico dos Solos e Formações Superficiais do Brasil. Parte I - Caracterização e repartição dos principais tipos de evolução pedogeoquímica. Rev Bras Geocienc 7(4): 11-22.

Melfi AJ, Cerri CC, Fritsch E And Formoso MLl. 1999. Tropical Soils: Genesis, distribution and degradation of lateritic pedological systems. In: FORMOSO MLL AND CERRI CC (Workshop on Tropical Soils), Academia Brasileira de Ciências, p. 7-30.

Meunier A. 2003. Argiles. Paris, Contemporary Publishing International - GB Science Publisher, 433 p.

Montes CR, Melfi AJ, Carvalho A, Vieira-Coelho AC and Formoso MLl. 2002. Genesis, mineralogy and geochemistry of kaolin deposits of the Jari River, Amapá State, Brazil. Clays Clay Miner 50: 494-503.

Muir IJ AND NesbitT HW. 1992. Controls on differential leaching of calcium and aluminum from labradorite in dilute electrolyte solutions. Geochim Cosmochim Acta 56: 3979-3985. 
NAHON DD. 1991. Introduction to the Petrology of Soils and Chemical Weathering. New York, USA, J Wiley \& Sons.

Pedro G. 1985. Le sol, composante majeure de la biosphere. Revue du Palais de la Découverte 15(4): 20-50.

Retallack GJ. 1990. Soils of the Past. London, Harper-Collins.

Roisenberg C, Formoso MLL AND Dani N. 2004. Ground water contamination caused by coal processing activities in the Candiota Region, State of Rio Grande do Sul, Brazil. In: ENVIROMENTAl Geochemistry in Tropical Countries, $4^{\text {th }}$ International Symposium, Búzios, RJ, Brazil, p. 237-241 (CD-ROM).

SILlÉn LG. 1961. The physical chemistry of sea water. In: OCEAnOGRAPHy, SEARS M (Ed), Amer Assoc for the Advanc of Sci, Washington DC, USA, p. 549-581. 